\title{
SEROTYPES AMONG LANCEFIELD-GROUP G STREPTOCOCCI ISOLATED IN NIGERIA
}

\author{
S. F. Lawal, A. O. Coker, E. O. Solanke \\ AND O. OGUNBI* \\ Department of Microbiology and Parasitology, College of Medicine, University of \\ Lagos, PMB 12003, Surulere, Lagos, Nigeria
}

\begin{abstract}
SUMmary. Six serotypes were found among haemolytic streptococci of Lancefield-group G. Members of these types accounted for about one-third of the strains isolated from human infections and carriers in Nigeria. The type antigens were similar to the M-protein antigens of group-A streptococci in that they were associated with the ability of the streptococci to survive and multiply in fresh human blood unless specific antibody was present. It was also possible to demonstrate in these group-G streptococci a non-type-specific $\mathrm{M}$-associated protein similar to that formed by M-positive strains of group-A streptococci.
\end{abstract}

\section{INTRODUCTION}

The pyogenic streptococci of Lancefield's group $\mathrm{G}$ are major pathogens in Nigeria (Ogunbi, 1971; Ogunbi, Lasi and Lawal, 1974a; Ogunbi et al., 1974b). Three different kinds of protein type-antigens have been described among particular strains of these organisms: the T-protein antigen numbered 16 (Griffith, 1934), the M-protein antigen 12 (Maxted and Potter, 1967) and the R-protein antigen first seen in group-A streptococci of M-type 28 (Maxted 1949). There is however no set scheme for the serotyping of these organisms. Previous work (Lawal, 1976) had confirmed that strains of this group produced streptolysin $\mathrm{O}$, hyaluronidase and deoxyribonuclease and had demonstrated, among some strains isolated in Nigeria, one M-protein antigen. The present work describes the identification of more M-protein antigens and the application of antisera against these proteins to the typing of strains.

\section{MATERIALS AND METHODS}

Streptococci. Six cultures of group-G streptococci were used for the preparation of typing sera. These had been selected from a set of 15 reference strains (see the table), which were also used in tests of the specificity of the sera. Another collection of 128 cultures of group-G streptococci, freshly isolated from human subjects in Lagos, were tested with the typing sera. These had been collected from the throat of carriers and from throat and skin lesions in persons suffering from local infections, rheumatic fever or glomerulonephritis. No attempt was made to demonstrate that the streptococci had caused any of the diseases.

Antisera. Typing sera were prepared in rabbits by means of whole-cell vaccines. A vaccine strain was grown in $250 \mathrm{ml}$ of Todd-Hewitt Broth (Difco) (DTHB), centrifuged, washed, and

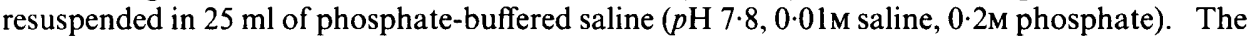
bacteria were killed by heating at $56^{\circ} \mathrm{C}$ for $30 \mathrm{~min}$. Adult rabbits were immunised by intravenous injection of $1 \mathrm{ml}$ of the vaccine twice weekly for 8-12 weeks.

The antisera were absorbed with an equal volume of a packed-cell deposit of a heat-killed heterologous group-G streptococcus (strain no. 17). An antiserum was mixed with the absorbing cells, was left on the bench for $1 \mathrm{~h}$, and was then centrifuged to produce a firmly packed deposit of cells. The serum was pipetted off.

Serological tests. Antigens were prepared by extraction with hot acid (Lancefield, 1940) of cultures grown overnight at $37^{\circ} \mathrm{C}$ in $50 \mathrm{ml}$ of DTHB. Precipitation reactions between antisera and extracted antigens were performed by the double-diffusion method in gel $(1 \%$ agarose in

\footnotetext{
* Requests for reprints should be sent to Professor O. Dosunmo-Ogunbi.
}

Received 2 Mar. 1981; revised version accepted 10 June 1981. 
distilled water) on microscope slides. Direct and indirect bactericidal tests (Maxted, 1956) were made in blood obtained from a suitable donor. M-associated protein (MAP) was detected by the method described by Widdowson, Maxted and Pinney (1971) in a complement-fixation test with serum fronı a suitable donor.

\section{RESULTS}

The unabsorbed antisera to the six vaccine strains gave precipitation lines in gel-diffusion tests against extracts of all vaccine strains. After absorption, a precipitation line formed against extracts of the homologous immunising strain only. One of the antisera, against type I, had been used earlier (Lawal, 1976) and was known to contain antibody against the T4 antigen found in some strains of Lancefield-group A. The vaccine strain for serotype $I$ in this respect resembles the strains of Lancefield-group G isolated by Hill and colleagues (1969) from an epidemic of pharyngitis. The collection of 128 strains tested for the presence of one or other of the type antigens I-VI contained respectively $4 \cdot 6 \%, 1 \cdot 8 \%, 6 \cdot 2 \%, 9 \cdot 4 \%, 2 \cdot 3 \%$ and $5 \cdot 5 \%$ members of these types. The untypable strains totalled $70 \cdot 2 \%$. The distribution of the 40 typable strains was as follows: type I, seven strains (all from skin or throat infections); type II, two strains (both from carriers); type III, eight strains (six from skin or throat infections, two from a survey of acute respiratory infections); type IV, 12 strains (all from skin or throat infections); type V, four strains (all from skin or throat infections); and type VI, seven strains (all from skin or throat infections). The six typing sera were tested against acid extracts of representatives of M-types 12 and 28 of group-A streptococci, and precipitation reactions were not observed.

Acid extracts of the typable group-G streptococci also contained considerable amounts of MAP (table), an antigen that is found in acid extracts of group-A streptococci only in association with an $M$ antigen. Most of the group-G streptococci also showed ability to survive and multiply in fresh human blood, a character that in group-A streptococci indicates the presence of an M antigen (table). There was however no clear association between the titre of MAP and the ability of a particular strain to multiply in human blood. In indirect bactericidal tests (not shown in the table), performed in the blood of the same donor, four type-I strains, including the type strain, which had grown profusely in the blood alone, were killed when type-I antiserum was added. The growth in human blood of the control strains-one strain of group A (T-type 12) and three of group G (one of type II and the others untypable) - was unaffected by type-I antiserum.

\section{TABLE}

Reference strains of group-G streptococci; serotype, presence of $M$-associated protein, and ability to multiply in fresh human blood

\begin{tabular}{cccc}
\hline $\begin{array}{c}\text { Strain } \\
\text { no. }\end{array}$ & Type & $\begin{array}{c}\text { Titre of } \\
\text { MAP }\end{array}$ & $\begin{array}{c}\text { Fold increase } \\
\text { in numbers of } \\
\text { streptococci* }\end{array}$ \\
\hline 23 & I & 80 & 103 \\
24 & I & 160 & 221 \\
26 & I & 320 & 62 \\
$28 \dagger$ & I & 160 & 260 \\
29 & I & 160 & 194 \\
$25 \dagger$ & II & 320 & 218 \\
$19 \dagger$ & III & 320 & 7 \\
$16 \dagger$ & IV & 80 & 30 \\
20 & V & 80 & 42 \\
$21 \dagger$ & V & 80 & 4 \\
$18^{\dagger}$ & VI & 320 & 90 \\
17 & NT & 20 & 137 \\
22 & NT & Negative & 13 \\
27 & NT & Negative & 30 \\
30 & NT & 20 & 9 \\
\hline
\end{tabular}

$\mathrm{MAP}=\mathrm{M}$-associated protein $\mathrm{NT}=$ not typable.

* Direct bactericidal test in fresh human blood.

+ Vaccine strain. 


\section{DISCUSSION}

A small collection of group-G streptococci had earlier been shown to have many of the characters of virulent group-A streptococci (Lawal, 1976). The present observations on the same strains indicate that most of them had two properties not found in group-A streptococci in the absence of an M antigen: the formation of MAP, and the ability to multiply in fresh human blood. Moreover, the addition to the blood of type-I antiserum resulted in the killing of strains of homologous but not of heterologous type.

Six types of group-G streptococci could be recognised by precipitation tests with hot-acid extracts and absorbed antisera. None of these antisera gave precipitation reactions with group-A streptococci of M-types 12 and 28; this indicated that our type antigens were distinct from M12 and R28. Our type-I antiserum did, however, agglutinate strains of group A, T-type 4. The T4 antigen has been described previously in strains of group G (Hill et al., 1969). All six of the group-G type antigens were recognised among a collection of 128 strains isolated in Nigeria.

Streptococci of Lancefield-group $\mathrm{G}$ appear to be of particular importance as pathogens in Nigeria (Ogunbi et al., 1974b). The finding that they produce antigens closely resembling the M proteins of group-A streptococci is of significance (1) because these antigens may be responsible for the pathogenicity of these streptococci, and (2) as a means of classifying them in epidemiological studies.

\section{REFERENCES}

Griffith, F. 1934. The serological classification of Streptococcus pyogenes. J. Hyg., Camb., $34,542$.

Hill, H. R., Caldwell, G. G., Wilson, E., Hager, D. and Zimmerman, R. A. 1969. Epidemic of pharyngitis due to streptococci of Lancefield group G. Lancet, 2, 371.

LANCEFIELD, R. C. 1940. Type-specific antigens M and T, of matt and glossy variants of group-A hemolytic streptococci. J. exp. Med., 71, 521 .

LAWAL, S. F. 1976. A study of biological characteristics of streptococci of Lancefield-groups C and $G$ in comparison with those associated with virulent streptococcus in group $A$, Thesis, Institute of Science Technology, London.

MAXTED, W. R. 1949. Occurrence of the M substance of type 28 group A in streptococci of Lancefield groups B, C and G. J. gen. Microbiol., 3, 1.

MAXTED, W. R. 1956. The indirect bactericidal test as a means of identifying antibody to the $M$ antigen of Streptococcus pyogenes. Br. J. exp. Path., 37, 415.

MAXTED, W. R. AND POTTER, E. V. 1967. The presence of type $12 \mathrm{M}$-protein antigen in group G streptococci. J. gen. Microbiol., 49, 119.

OGUNBI, O. 1971. A study of beta haemolytic streptococci in throats, noses and skin lesions in a Nigerian (Lagos) urban population. J. Niger. med. Ass., 1, 159.

OGUNBI, O., LASI, Q. AND LaWAL, S. F. 1974a. An epidemiological study of beta-haemolytic streptococcal infection in a Nigerian (Lagos) urban population. Proceedings of the fifth international symposium on Streptococcus pyogenes, Amsterdam, 1972, edited by M. J. Haverkorn, Excepta Medica, Amsterdam, International congress series no. 317.

OgunBi, L. O. O., LaWAL, A., Lasi, Q. ANd OgunBi, O. 1974b. Streptococcal pyoderma in a Lagos school population. Niger. med. J., 4, 178.

WidDowson, J. P., MAXTED, W. R. AND PinNEY, A. M. 1971. An M-associated protein antigen (MAP) of group A streptococci. J. Hyg., Camb., 69, 553. 